\title{
Negative effects of Corbicula fluminea over native freshwater mussels
}

\author{
Noé Ferreira-Rodríguez $\cdot$ Ronaldo Sousa $\cdot$ Isabel Pardo
}

Received: 27 April 2016/Revised: 26 September 2016/Accepted: 16 November 2016/Published online: 24 November 2016 (C) Springer International Publishing Switzerland 2016

\begin{abstract}
The global decline of freshwater mussels is related with a great variety of factors, including the introduction of invasive species. However, the possible effects of other invasive bivalves, such as the Asian clam Corbicula fluminea (Müller, 1774), remain mainly unknown and highly speculative with very few manipulative experiments addressing this issue. In this study, field and laboratory experiments were conducted to assess the possible negative effects of $C$. fluminea on the native freshwater mussel Unio
\end{abstract}

Guest editors: Manuel P. M. Lopes-Lima, Ronaldo G. Sousa, Lyuba E. Burlakova, Alexander Y. Karatayev \& Knut Mehler / Ecology and Conservation of Freshwater Bivalves

N. Ferreira-Rodríguez $(\bowtie) \cdot$ I. Pardo

Departamento de Ecología y Biología Animal, Facultad de Biología, Campus As Lagoas - Marcosende,

Universidad de Vigo, 36310 Vigo, Spain

e-mail: noeferreira@uvigo.es

N. Ferreira-Rodríguez $\cdot$ I. Pardo

ECIMAT - Estación de Ciencias Mariñas de Toralla, Illa de Toralla, 36331 Vigo, Spain

R. Sousa

Department of Biology, CBMA - Centre of Molecular and Environmental Biology, University of Minho, Campus de Gualtar, 4710-057 Braga, Portugal

R. Sousa

CIIMAR/CIMAR - Interdisciplinary Centre of Marine and Environmental Research, University of Porto, Rua dos Bragas 289, 4050-123 Porto, Portugal delphinus Spengler, 1783. Growth, physiological condition, and the locomotor activity were assessed in $U$. delphinus at increasing $C$. fluminea density. $U$. delphinus exhibited lower growth, lower physiological condition, and higher locomotor activity at higher C. fluminea density, which may suggest that this unionid is negatively affected by $C$. fluminea and may be displaced to less favorable habitats. Although we were not able to establish the main mechanism(s) responsible for these results, possibilities include competition for food resources, competition for space which may result in mussel displacements and/or changes in microhabitat features as a result of bioturbation activities, and production of feces and pseudofeces by $C$. fluminea.

Keywords Unio delphinus - Conservation · Competition · Carbohydrate · Behavior - Invasive species $\cdot$ Asian clam

\section{Introduction}

Freshwater mussels (order Unionoida) are one of the most imperiled faunal groups on the planet, with high rates of extinctions (Lydeard et al., 2004; Strayer et al., 2004; Lopes-Lima et al., 2014, 2016). Their decline in spatial distribution and abundance has been related to a great variety of factors, which include habitat loss and fragmentation associated with dams or other type 
of physical obstacles and water abstraction, dredging, and channelization, water quality degradation due to eutrophication or other types of pollution, overexploitation, and climate change (Vaughn \& Taylor, 1999; Williams et al., 1998; Anthony \& Downing, 2001; Patzner \& Müller, 2001; Downing et al., 2010; Santos et al., 2015; Sousa et al., 2016; Zieritz et al., in press). In addition to the above-mentioned factors, during the last decades the introduction of invasive species has been also described as an important threat to freshwater mussel conservation. A great emphasis has been given to the negative effects imposed by invasive bivalves such as the zebra mussel Dreissena polymorpha (Pallas, 1771) on freshwater mussels (Hebert et al. 1991; Sousa et al., 2011a, 2014; Bódis et al., 2014; Krebs et al., 2015).

The Asian clam Corbicula fluminea (Müller, 1774) has also been cited as an important threat to freshwater mussel conservation (Leff et al., 1990). This species was first introduced in the United States of America in the first half of the twentieth century, then in South America in the late 1960s/beginning of the 1970s. It reached Europe in the late 1970s/beginning of the 1980s and North Africa in the last decade (for a recent review see Crespo et al., 2015). Therefore, in addition to the native range in Asia, nowadays the species is present in North and South America, North Africa, and in almost all European river basins, from the Iberian Peninsula in the Southwest to Ireland and UK in the North and to Bulgaria and Romania in the East (Crespo et al., 2015). Krumholz et al. (1969) were the first to suggest the possible negative impacts of $C$. fluminea on native freshwater mussels. Recent studies have shown its potential to impact both benthic and pelagic biological communities, including native bivalve populations (Isom, 1986; McMahon, 1991; Vaughn \& Spooner, 2006; Ilarri et al., 2012, 2014; Novais et al., 2015, 2016b). Despite the potential threat of $C$. fluminea to aquatic ecosystems and their biodiversity, the impact on native bivalve species is understudied and there is a lack of consensus about the strength of interactions between $C$. fluminea and native bivalves living in sympatry (Strayer, 1999). Generally, the evidence is weak and most of the available information comes from field observations. This information is usually correlative or is inferred from the published literature, which mainly covers North American ecosystems (Clarke, 1988; Strayer, 1999). The reality is that a limited number of manipulative experiments has established clear links between the presence of $C$. fluminea and the decline of freshwater bivalves; being most of these studies on sphaeriid clams (Strayer, 1999; Sousa et al., 2008c, d, 2011b). Some of the conclusions of these studies suggest that dense populations of $C$. fluminea may compete with freshwater bivalves for space and/ or food resources (Strayer, 1999; Novais et al., 2016a). In addition, negative impacts on native freshwater mussels are also likely to occur through other mechanisms, such as possible ingestion of unionid sperm, glochidia, or newly metamorphosed juveniles by $C$. fluminea; massive mortalities of $C$. fluminea which result in unionid mortality by ammonia toxicity (Cherry et al., 2005); and bioturbation activities and organic matter enrichment due to the production of feces and pseudofeces by $C$. fluminea, which may alter sediment biochemistry and impair the survival of unionids. However, all these mechanisms remain highly speculative and to date have not been properly assessed (Sousa et al., 2008b). Furthermore, $C$. fluminea has a typical opportunistic life cycle with biological traits comprising fast growing, short lifespan, early maturation, and high fecundity, among others (Sousa et al., 2008b). By contrast, unionid mussels are usually slow-growing species, with a long lifespan and complex life history dependent of host fishes (Lopes-Lima et al., 2014). In addition to these biological traits, the invasive success of $C$. fluminea relies also on its higher tolerance to abiotic factors such as $\mathrm{pH}$, salinity, and emersion than native species (Johnson \& McMahon, 1998; McMahon, 2000, 2002; Sousa et al., 2008b; Ferreira-Rodríguez \& Pardo, 2014, 2016).

The freshwater mussel Unio delphinus Spengler, 1783 is an Iberian endemism from western basins such as Miño, Douro, Tajo, and Guadiana, among others (Pérez-Quintero, 2011; Reis et al., 2013; Morais et al., 2014; Froufe et al., 2016). This species is listed as near threatened by the IUCN Red List (Araujo, 2011). The abundance and spatial distribution of $U$. delphinus populations declined in the last decades, which makes them imperative to rapidly reclassify its status (Araujo et al., 2009; Araujo, 2011). The reasons for this rapid decline are not well established. Some authors have pointed out the possibility of negative effects of $C$. fluminea on $U$. delphinus, especially when both species are found in sympatry presenting the invasive species a high density (Sousa et al., 2008a, f; Novais 
et al., 2016a). However, this suggestion remains speculative and, to date, no study has addressed this issue and no attempt has been made to establish the main mechanisms behind the possible negative effects of $C$. fluminea on $U$. delphinus, or other unionid species. Given this context, this study aims to determine if $C$. fluminea interacts negatively with $U$. delphinus, potentially competing for food resources and/or space. We hypothesized that $U$. delphinus will be negatively affected, which may result in lower growth, lower physiological condition, and higher locomotor activity. In addition, we hypothesized that this interaction will be density dependent. To evaluate these hypotheses, both field and laboratorial experiments were performed to assess growth, physiological condition (carbohydrate content), and activity pattern (locomotor activity) of $U$. delphinus at different $C$. fluminea density.

\section{Materials and methods}

Inter-specific assays using the invasive species $C$. fluminea and the native species $U$. delphinus comprised two different approaches: (i) a field experiment to determine possible negative effects on growth and physiological condition of $U$. delphinus under different C. fluminea density and (ii) a laboratory experiment to assess possible alteration on the activity pattern of $U$. delphinus under different $C$. fluminea density.

Animal collection

Specimens of $C$. fluminea (5220 individuals, average length $( \pm \mathrm{SD})$ of $21.8 \pm 0.7 \mathrm{~mm})$ and $U$. delphinus (104 individuals, average length $( \pm \mathrm{SD})$ of $57.4 \pm 2.8 \mathrm{~mm}$ ) were collected with permission from the competent authority (Servizo de Conservación da Natureza, Xunta de Galicia) in the River Miño at $1 \mathrm{~m}$ depth with a kick net (1 mm mesh size).

\section{Field experiment}

The field study was conducted in the River Miño (NW of the Iberian Peninsula). The river basin covers approximately $17,582 \mathrm{~km}^{2}$. The study area selected for the field experiment was located around $40 \mathrm{~km}$ upstream from the river mouth in the left bank $\left(42^{\circ} 04^{\prime} 36.81^{\prime \prime} \mathrm{N}, 8^{\circ} 31^{\prime} 00.25^{\prime \prime} \mathrm{W}\right.$, datum WGS 84$)$, in a slow flowing site where both $C$. fluminea and $U$. delphinus species co-exist in sympatry. The experiment was carried out in a very shallow area (total area of $20 \mathrm{~m}^{2}, 3 \mathrm{~m}$ away from the bank at $1 \mathrm{~m}$ depth during summer, having a $100 \%$ canopy cover) with permanent freshwater conditions. In this area, the river has an annual average discharge of $326 \mathrm{~m}^{3} \mathrm{~s}^{-1}$, with summer minimum values around $47 \mathrm{~m}^{3} \mathrm{~s}^{-1}$ and spring maximum values around $1350 \mathrm{~m}^{3} \mathrm{~s}^{-1}$ (SAICA Water Quality Network Station N015; Miño-Sil River Basin Authority). Great variations in discharge may occur on a daily basis due to the operation of a dam located $30 \mathrm{~km}$ upstream of the study site.

After collection, mussels were numbered using DYMO labels, and their length was measured with a digital caliper (precision of $0.001 \mathrm{~mm}$ ). Individual $U$. delphinus were placed in a plastic box $(400 \times 300 \times$ $100 \mathrm{~mm}$ ) covered with plastic net (mesh size of $10 \mathrm{~mm}$ ) and filled with sandy substrate (average percentage of grain size categories $\pm \mathrm{SD}$ : grain size $<0.25 \mathrm{~mm}$ : $18.942 \pm 0.816 \%$; grain size $0.25-0.5 \mathrm{~mm}: 43.256 \pm$ $3.226 \%$; grain size $0.5-1 \mathrm{~mm}: 37.691 \pm 2.377 \%$; grain size $>1 \mathrm{~mm}$ : $0.111 \pm 0.032 \%$; and organic matter content: $0.342 \pm 0.283 \%$ ). To examine inter-specific effects on $U$. delphinus at different $C$. fluminea density, we used four $C$. fluminea treatments of 0 (control), 100, 1000, and 2000 ind. $\mathrm{m}^{-2}(0,12,120$, and $240 C$. fluminea individuals per box, respectively), using a similar size class (and biomass) between treatments in order to avoid possible bias due to size. Each treatment was replicated 10 times and boxes were randomly distributed in the river. The experiment lasted more than 5 months (between May 13 and October 31, 2015). At the end of the experiment, $U$. delphinus specimens were removed and transported to the laboratory. There, $U$. delphinus specimens were re-measured with a digital caliper and growth was calculated based on the difference between the initial and final measurements. The following abiotic factors in the water column were monthly measured from May to October 2015: temperature, conductivity, total dissolved solids, redox potential, salinity, dissolved oxygen, $\mathrm{pH}$, nitrites, nitrates, ammonia, and phosphates. Information for the first seven abiotic factors was obtained in situ near the bottom, using a multiparametrical probe YSI EXO2. Nitrites, nitrates, ammonia, and phosphates were determined by colorimetric methods using the Palintest 270 standard photometer 7000 following the methodology described in Sousa et al. (2008c). 
Table 1 Summary of the criteria used for scoring the activity of Unio delphinus (modified from Xie \& Burnell, 1995)

\begin{tabular}{ll}
\hline Score & Criteria \\
\hline 1 & Shell valves closed \\
2 & Shell valves opened and siphoning \\
3 & Shell valves opened and foot clearly visible \\
4 & Shell valves opened and foot extended out half of its full length \\
5 & Shell valves opened and foot extended out in its full length \\
\hline
\end{tabular}

The physiological status of each $U$. delphinus individual was determined as carbohydrate content, which is commonly used as a biomarker to assess energy storage in freshwater bivalves (Sousa et al., 2011a; Pilotto et al., 2016). To assess the carbohydrate content, the soft tissue (whole body) of mussels was dried at $60^{\circ} \mathrm{C}$ for $48 \mathrm{~h}$ in an oven and then ground to fine powder. The carbohydrate content was measured colorimetrically using the phenol-sulphuric acid method described in Baker \& Hornbach (2000).

\section{Laboratory experiment}

The laboratory study was conducted in September 2014 in the Marine Science Station of Toralla (ECIMAT, University of Vigo, Vigo, Spain). After collection (using the same methodology as described above), $64 U$. delphinus (average length $( \pm \mathrm{SD})$ of $56.4 \pm 7.0 \mathrm{~mm}$ ) and 1500 C. fluminea individuals (average length $( \pm \mathrm{SD})$ of $25.0 \pm 1.0 \mathrm{~mm}$ ) were transported in aerated buckets with water to the ECIMAT. In the laboratory, mussels were numbered (DYMO labels), and their length was measured with a digital caliper. Mussels and clams were kept separately in 301 aquaria for one week, with constant aeration and daily supply of freshwater microalgae Raphidocelis subcapitata (Korshikov) Nygaard, Komárek, J. Kristiansen and O. M. Skulberg $\left(10,000\right.$ cells $\left.\mathrm{ml}^{-1}\right)$, in order to acclimate to laboratory conditions $\left(20^{\circ} \mathrm{C}\right.$ and $12: 12 \mathrm{~h}$ light:darkness cycle). After acclimatization, experiments on mussel activity were conducted by placing two mussels in 301 aquaria without the substrate daily fed with $R$. subcapitata $\left(10,000\right.$ cells $\left.\mathrm{ml}^{-1}\right)$ for four days. To examine inter-specific effects on mussel activity at different $C$. fluminea densities that naturally occur in the wild (Ferreira-Rodríguez \& Pardo, 2014), we used eight $C$. fluminea treatments ( 0 -control, 25, 50, 75, 150, 300, 600, and 1200 ind. $\mathrm{m}^{-2}$ ). All treatments were replicated four times, using a single $C$. fluminea size class in order to avoid possible size bias.

Under experimental conditions, $U$. delphinus were mostly active during the day (data not shown). Hence, the activity of $U$. delphinus $(n=64)$ was always monitored in the morning (07:00-08:00 h, GMT), for 4 consecutive days. Mussels' activity for each treatment was measured as the average activity score of four consecutive observations using a criteria modified from Xie \& Burnell (1995), as shown in Table 1. To allow animals to behave normally, mussels were observed once daily for siphoning and foot extension, without being disturbed (before daily feeding, cleaning, water exchange, and abiotic data collection). At the end of the experiment all native mussels were returned to the wild.

\section{Data analysis}

Growth and carbohydrate concentration data distributions were successfully tested for normality and homogeneity of variance using Kolmogorov-Smirnov $\mathrm{Z}$ and Levene's tests, respectively. The $C$. fluminea density effect was analyzed using univariate General Linear Model (GLM). Growth and carbohydrate content were the dependent variables and $C$. fluminea density was the fixed factor, using size as covariable for growth analysis. Growth and carbohydrate extreme outliers were identified as values lying above UQ + $3 \times$ IQR (Box plots; Zhang et al., 2009) and excluded from overall analysis. Differences in growth and carbohydrate concentration between treatments were tested with the Tukey HSD method. In the laboratory experiment, average activity score was graphically represented, two densities (low C. $f u$ minea density: $\leq 300$ ind. $\mathrm{m}^{-2}$; high $C$. fluminea density: $>300$ ind $\mathrm{m}^{-2}$ ) were established and the activity score was compared using univariate general linear model (GLM). Activity score was the dependent 
Table 2 Average, minimum, maximum, and standard error (SE) values of the abiotic factors measured from May to October 2015 in the River Miño study site

\begin{tabular}{lccrr}
\hline & Average & Minimum & Maximum & \pm SE \\
\hline Temperature $\left({ }^{\circ} \mathrm{C}\right)$ & 19.69 & 16.35 & 22.26 & 1.09 \\
Conductivity $\left(\mu \mathrm{S} \mathrm{cm}^{-1}\right)$ & 98.83 & 87.00 & 110.00 & 3.96 \\
Total dissolved solids $\left(\mathrm{mg} \mathrm{l}^{-1}\right)$ & 0.063 & 0.50 & 0.70 & 0.00 \\
Redox potential $(\mathrm{mV})$ & 60.72 & 53.10 & 70.00 & 2.93 \\
Salinity $(\mathrm{psu})$ & 0.05 & 0.04 & 0.05 & 0.00 \\
Dissolved oxygen $\left(\mathrm{mg} \mathrm{l}^{-1}\right)$ & 9.99 & 9.01 & 10.71 & 0.28 \\
pH & 7.35 & 7.21 & 7.51 & 0.05 \\
Nitrites $\left(\mathrm{mg} \mathrm{l}^{-1}\right)$ & 0.04 & 0.01 & 0.08 & 0.01 \\
Nitrates $\left(\mathrm{mg} \mathrm{l}^{-1}\right)$ & 1.24 & 0.72 & 1.56 & 0.13 \\
Ammonia $\left(\mathrm{mg} \mathrm{l}^{-1}\right)$ & 0.06 & 0.00 & 0.10 & 0.01 \\
Phosphates $\left(\mathrm{mg} \mathrm{l}^{-1}\right)$ & 0.09 & 0.05 & 0.12 & 0.01 \\
Hardness $\left(\mathrm{mg} \mathrm{l}^{-1}\right)$ & 15.83 & 10.00 & 25.00 & 2.01 \\
\hline
\end{tabular}

variable and density was the fixed factor. All analyses were performed with SPSS v.18 using a significance level of 0.05 .

\section{Results}

Abiotic factor values are shown in Table 2 and represent typical spring and summer conditions for the River Miňo.

No mortality in $U$. delphinus (or $C$. fluminea) was recorded in any treatment during the field experiment. $U$. delphinus individuals increased in length during the experiment (Fig. 1). The GLM analysis provides evidence for an effect of $C$. fluminea density on growth. In fact, growth was significantly higher in the control treatment (no $C$. fluminea) compared to individuals growing in sympatry with $C$. fluminea $\left(F_{3,40}=3.674, P=0.021\right)$. Average $( \pm \mathrm{SE})$ growth was greater in the control treatment $(0.599 \pm$ $0.098 \mathrm{~mm})$ when compared to 100 ind. $\mathrm{m}^{-2}(0.407 \pm$ $0.056 \mathrm{~mm}), 1000$ ind. $\mathrm{m}^{-2}(0.276 \pm 0.102 \mathrm{~mm})$, and 2000 ind. $\mathrm{m}^{-2} \quad(0.233 \pm 0.101 \mathrm{~mm}) \quad$ C. fluminea treatments.

Corbicula fluminea density affected significantly the carbohydrate content of $U$. delphinus $\left(F_{3,35}=\right.$ $3.822, P=0.019$; Fig. 2$)$. Average $( \pm \mathrm{SE})$ carbohydrate content was $14.078 \pm 0.357 \mathrm{mg} \mathrm{g}^{-1}$ in the control treatment and $12.775 \pm 0.600 \mathrm{mg} \mathrm{g}^{-1}, \quad 11.562 \pm$ $0.838 \mathrm{mg} \mathrm{g}^{-1}$, and $9.930 \pm 0.331 \mathrm{mg} \mathrm{g}^{-1}$ in 100 , 1000 , and 2000 ind. $\mathrm{m}^{-2}$ C. fluminea treatments, respectively.

The average activity score of $U$. delphinus was higher $\left(F_{7,384}=11.343, \quad P=0.001\right)$ in mussels

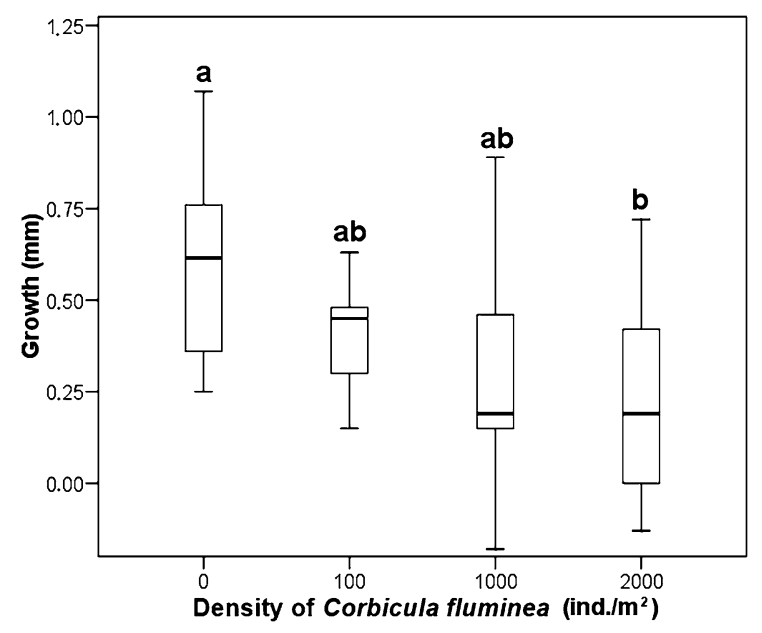

Fig. 1 Growth of Unio delphinus at four C. fluminea densities. Box plots represent growth in ten $U$. delphinus at the end of the experiment. Each box shows the lower and upper quartile values, and the black line indicates the median value. The bars indicate the standard error, and extreme outliers identified as values lying above UQ $+3 \times \mathrm{IQR}$ are omitted. Averages with a common letter do not differ from each other based on Tukey's HSD pairwise comparisons at the $P<0.05$ level of significance

exposed to high ( $>300$ ind. $\mathrm{m}^{-2}$, Average activity score $\pm \mathrm{SE}=2.57 \pm 0.891$; Fig. 3) compared to low C. fluminea density $\left(\leq 300\right.$ ind. $\mathrm{m}^{-2}$, Average activity score $\pm \mathrm{SE}=2.29 \pm 0.65$; Fig. 3).

\section{Discussion}

In the present study we demonstrated that under experimental conditions, the invasive clam $C$. 


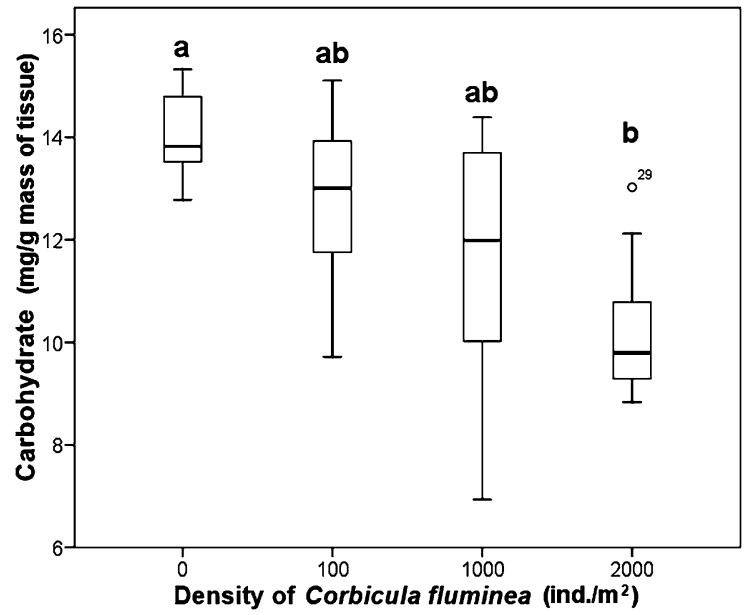

Fig. 2 Carbohydrate content of Unio delphinus at four $C$. fluminea densities. Box plots represent carbohydrate content in ten $U$. delphinus at the end of the experiment. Each box shows the lower and upper quartile values, and the black line indicates the median value. The bars indicate the standard error and circles extreme values (middle outliers). Extreme outliers identified as values lying above UQ $+3 \times$ IQR are omitted. Averages with a common letter do not differ from each other based on Tukey's HSD pairwise comparisons at the $P<0.05$ level of significance

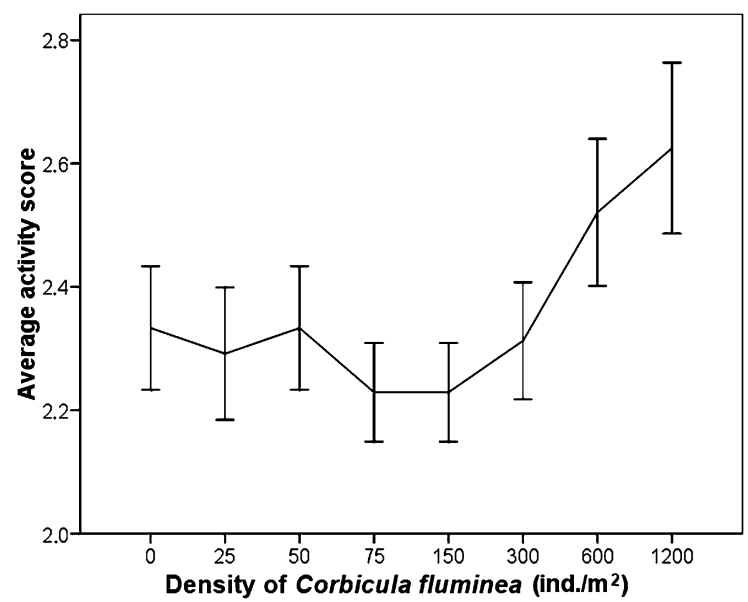

Fig. 3 Average activity scores in Unio delphinus exposed to different Corbicula fluminea density levels. Error bars represent standard error

fluminea influences negatively the performance of the native freshwater mussel $U$. delphinus. Although some earlier studies (e.g., Kraemer, 1979) have shown some evidence of native unionid species declining in response to $C$. fluminea invasion in disturbed habitats, little is known about the impact of this invasive clam over native mussel populations. Thus, this study is one of the first to assess the negative impact of this invasive clam on native freshwater mussels. In one hand, our field experiment showed that increasing $C$. fluminea densities resulted in significant slower growth and physiological condition in $U$. delphinus. On the other hand, our laboratory experiment showed significant increase in $U$. delphinus activity at high $C$. fluminea density, which may suggest an increased energy expenditure. In addition, this increased activity can be interpreted as an attempt of $U$. delphinus to avoid interaction with $C$. fluminea. Thus, it seems likely that high $C$. fluminea density may result in the displacement of native mussel species.

Results from our field experiment showed that $U$. delphinus growth was affected by $C$. fluminea. Most adult freshwater mussel species are slow-growing bivalves and typically just grow a few millimeters on a yearly basis (Neves \& Moyer, 1988; Haag \& Rypel, 2010). In contrast, $C$. fluminea usually presents much higher growth than unionids (maximum growth of $C$. fluminea in River Miño around $20 \mathrm{~mm} \mathrm{year}^{-1}$ in the first year of the life cycle; Sousa et al., 2008e), due to its higher filtration and assimilation rates and higher feeding plasticity (in addition to filter feeding, $C$. fluminea may also feed on organic matter deposits available in the sediments; McMahon, 2002). This higher feeding efficiency may represent a short-term advantage, mainly in oligotrophic environments. Therefore, when resources are limited in the water column, as in our study area (Dias et al., 2014), invasive fast-growing bivalves may negatively affect the survival and growth of native bivalves and may have a competitive advantage due to their higher trophic plasticity (Novais et al., 2016a). Similar results have been reported by Crooks (2001) in estuarine ecosystems using native and invasive bivalves.

Corbicula fluminea may also influence indirectly the unionids' physiological condition. Our results showed a decline in carbohydrate concentration as response to higher $C$. fluminea density, possibly by forcing $U$. delphinus to rely on stored reserves under these increasing $C$. fluminea densities representing stressful conditions (Gabbott \& Bayne, 1973; Newell, 1985). These reserves are accumulated as carbohydrate in freshwater bivalves and are used for key metabolic and physiological processes. Therefore, carbohydrate concentrations serve as a biomarker of health condition and may reflect stress conditions in freshwater mussels, such as those resulting from $C$. 
fluminea invasion (Lagadic et al., 1997; HamzaChaffai et al., 2003).

Results from our laboratory experiment showed an increase in activity of $U$. delphinus when subjected to high $C$. fluminea densities. The ecological requirements of both species can sometimes overlap; habitats with muddy and sandy sediments rich in organic matter are easily colonized by unionids as well as $C$. fluminea (Vaughn \& Spooner, 2006; Sousa et al., 2007; Ferreira-Rodríguez \& Pardo, 2014). Indeed, in the study area where the field experiment was conducted (River Miño) both species live in sympatry (Sousa et al., 2005). Given our laboratory results, $C$. fluminea density above 300 ind. $\mathrm{m}^{-2}$ may represent stressful conditions for $U$. delphinus individuals, displacing them to lower quality habitats. However, it must be taken into account that predictions made under experimental conditions may fail in nature. For example, Englund \& Heino (1994) have demonstrated increases in daily activity rhythm in caged mussels. Hence, since caged mussels are unable to burrow to great depths, and activity patterns depend on a wide range of abiotic (e.g., temperature, light, endogenous rhythms, or algal concentrations; McCorkle et al. 1979; Amyot \& Downing, 1997; Riisgård et al., 2003) and biotic (e.g., parasitism, predation) factors, more studies under natural conditions are necessary to better understand the relationship of the observed activity pattern in C. fluminea density.

Although we demonstrate the negative effects of $C$. fluminea over $U$. delphinus, our experimental approaches were not able to determine the main mechanisms behind this interaction. However, interspecific competition for space and/or resources and abiotic changes resulting from high $C$. fluminea density may be involved in the negative impacts they cause on native unionids. By definition, competition is a negative interaction between two or more species of the same trophic level, which exploit the same shared, limiting resources (Connell, 1983). Our results suggest that $U$. delphinus was negatively affected and that this may be due to $C$. fluminea's superior exploitative competitive ability, as described above. It seems reasonable to expect that there could be some reciprocity (Connell, 1983), with $U$. delphinus negatively affecting $C$. fluminea. However, a different experimental approach will be necessary to prove this situation.

The possible resulting biological competitive interaction is often assumed to be a key aspect influencing invasion success and many examples in the literature show how invasive species can outcompete native species in terms of space (Carlton et al., 1999; McIntosh et al., 1992) and food resources (Byers, 2000; Alcaraz et al., 2008), mainly when those are scarce and become insufficient to support all organisms (Wiens, 1977; Gurnell et al., 2005). First, food resources are a limiting factor in any animal species. Recent experimental works with mollusks, including gastropods (Byers, 2000) and bivalves (Byers, 2005; Crooks, 2005), have demonstrated that in a competition context the resource levels may experience differences in growth. However, the real advantage of one species depends on its ability to effectively convert resources into energy (Murdoch et al., 1996; Byers, 2000). A reduction in energy uptake due to resource competition with $C$. fluminea is a very likely explanation for the reduced growth in $U$. delphinus. Several examples in the literature exist relating these differences in growth with inter-specific competition (e.g., Bayne et al., 1979; Connell, 1983; Belanger, 1991; Cope \& Winterbourn, 2004). Other similar studies, performed in the field and laboratory in USA and UK, have shown that zebra mussels also reduced the energy stored in freshwater mussels due to food resources competition (Baker \& Hornbach, 2000; Sousa et al., 2011a). This situation resulted in decreases of native unionids' physiological condition, compromising their reproduction and recruitment rates in areas with high density of invasive bivalves (Tlili et al., 2011; Tankoua et al., 2012). Second, space is also a limiting factor for benthic invertebrates and some studies have shown that the potential bioturbation by $C$. fluminea could influence benthic characteristics, displacing and/or reducing available habitats for native species, mainly at high density (Hakenkamp et al., 2001; Vaughn \& Hakenkamp, 2001). Besides displacement to lower quality habitats, competition has been linked to risky behavioral alterations (e.g., mortality due to high flow rates or predation; Block et al., 2013) and reductions in reproductive success because mussels depend on spatial aggregations to maximize fertilization success (Downing et al., 1993). In addition, behavioral impairments increase energy expenditure and represent an additional energetic cost (Schoener, 1983; Trueman, 1983) that could compromise the expensive gamete production (especially in females). Until now, many locomotor activities were previously described in freshwater mussels in 
association with mussel community structure (Allen \& Vaughn, 2009), seasonal changes in abiotic factors (Amyot \& Downing, 1997), reproduction (Amyot \& Downing, 1998), or predation (Jokela \& Mutikainen, 1995), but never in association with invasive species. Finally, C. fluminea can be responsible for changes in abiotic conditions, which may interfere negatively with native unionids. For example, bioturbation, production of feaces and pseudofeaces, or C. fluminea massive mortalities can change sediment characteristics, organic matter content, oxygen, and nutrient cycling impairing the survival of freshwater mussels (Sousa et al., 2014). Unfortunately, many of these abiotic changes and their direct negative effects on freshwater mussels remain untested and further studies are necessary to clarify these effects.

Our results could explain, in part, the loss of up to $30 \%$ of $U$. delphinus populations in the Iberian Peninsula in the last decades (Araujo, 2011). However, the introduction of new competitors rarely causes native species extinctions, with most existing studies only able to show declines in abundance but not extinction or extirpation (Bruno et al., 2005). In addition, the introduction of invasive species are not the unique threat affecting Iberian Peninsula unionid populations, as many ecosystems are currently subjected to habitat loss, fragmentation and degradation due to anthropogenic activities, changes in the hydrologic regime due to dams and impoundments, water abstraction, loss of host fish populations, and water pollution (Araujo et al., 2009; Araujo, 2011; Douda et al., 2013). Therefore, the introduction of invasive species such as $C$. fluminea to ecosystems where native mussels are already in decline is an additional threat that should not be neglected.

\section{Conclusion}

The biological traits (e.g., long life cycle, slow growth, parasitic larval stage) of freshwater mussels render them particularly susceptible to abiotic and biotic disturbances (Lopes-Lima et al., 2014, 2016). In this study, we have shown that $C$. fluminea invasion may negatively affect the native freshwater mussel $U$. delphinus in Iberian Peninsula, whose populations are already declining. Our findings suggest that $C$. fluminea can negatively affect growth, physiological condition, and locomotor activity of native unionids, and this interaction is particularly detrimental to $U$. delphinus at sites with high $C$. fluminea density. Therefore, future studies should aim to evaluate the impact of $C$. fluminea on other threatened mussel species, evaluate similar effects on unionid juveniles (possibly even more vulnerable than adults), and assess possible spatial (sites subjected to different abiotic conditions and food resource levels) and temporal (winter versus summer conditions) variations. Given the widespread distribution of $C$. fluminea and the declining conservation status of many freshwater mussel species worldwide, the effects of Asian clams should be taken into account in future management actions devoted to the conservation of native unionids.

Acknowledgements N. F-R was supported from a predoctoral fellowship from the Autonomic Govern of Galicia (Xunta de Galicia Plan I2C, PRE/2013/400) and a scholarship for a research stay abroad from the University of Vigo (A.P.: 00VI 131H 481.02). Authors thank Jon Mageroy for valuable suggestions on an earlier version of the manuscript. RS also acknowledge the support of the strategic programme UID/BIA/ 04050/2013 (POCI-01-0145-FEDER-007569) funded by national funds through the FCT I.P. and by the ERDF through the COMPETE2020-Programa Operacional Competitividade e Internacionalização (POCI). This study was conducted as part of the project FRESHCO: Multiple implications of invasive species on Freshwater Mussel coextinction processes, supported by FCT (contract: PTDC/AGRFOR/1627/2014). The authors would like to thank the anonymous reviewers for their helpful comments that improve the quality of the manuscript.

\section{References}

Alcaraz, C., A. Bisazza \& E. García-Berthou, 2008. Salinity mediates the competitive interactions between invasive mosquitofish and an endangered fish. Oecologia 155: 205-213.

Allen, D. C. \& C. C. Vaughn, 2009. Burrowing behavior of freshwater mussels in experimentally manipulated communities. Journal of the North American Benthological Society 28: 93-100.

Amyot, J.-P. \& J. A. Downing, 1997. Seasonal variation in vertical and horizontal movement of the freshwater bivalve Elliptio complanata (Mollusca: Unionidae). Freshwater Biology 37: 345-354.

Amyot, J.-P. \& J. A. Downing, 1998. Locomotion in Ellipo complanata (Mollusca: Unionidae): a reproductive function? Freshwater Biology 39: 351-358.

Anthony, J. L. \& J. A. Downing, 2001. Exploitation trajectory of a declining fauna: a century of freshwater mussel fisheries in North America. Canadian Journal of Fisheries and Aquatic Sciences 58: 2071-2090. 
Araujo, R., 2011. Unio delphinus. In IUCN Red List of Threatened Species. Version 2015.3 [available on internet at http://www.iucnredlist.org/]. Accessed 15th November 2015.

Araujo, R., J. Reis, A. Machordom, C. Toledo, M. J. Madeira, I. Gómez, J. C. Velasco, J. Morales, J. M. Barea, P. Ondina \& I. Ayala, 2009. The naiads of the Iberian Peninsula. Iberus 27: 7-72.

Baker, S. M. \& J. Hornbach, 2000. Physiological status and biochemical composition of a natural population of unionid mussels (Amblema plicata) infested by zebra mussels (Dreissena polymorpha). American Midland Naturalist 143: 443-452.

Bayne, B. L., M. N. Moore, J. Widdows, D. R. Livingstone \& P. Salkeld, 1979. Measurement of the responses of individuals to environmental stress and pollution: studies with bivalve molluscs. Philosophical Transactions of the Royal Society B 286: 563-581.

Belanger, S. E., 1991. The effect of dissolved oxygen, sediment, and sewage treatment plant discharges upon growth, survival and density of Asiatic clams. Hydrobiologia 218: 113-126.

Block, J. E., G. W. Gerald \& T. D. Levine, 2013. Temperature effects on burrowing behaviors and performance in a freshwater mussel. Journal of Freshwater Ecology 28: 375-384.

Bódis, E., B. Tóth \& R. Sousa, 2014. Impact of Dreissena fouling on the physiological condition of native and invasive bivalves: interspecific and temporal variations. Biological Invasions 16: 1373-1386.

Bruno, J. E., J. D. Fridley, K. D. Bromberg \& M. D. Bertness, 2005. Insights into biotic interactions from studies of species invasions. In Sax, D. F., J. J. Stachowicz \& S. D. Gaines (eds), Species Invasions: Insights Into Ecology, Evolution, and Biogeography. Sinauer, Sunderland: 13-40.

Byers, J. E., 2000. Competition between two estuarine snails: implications for invasions of exotic species. Ecology 81 : $1225-1239$.

Byers, J. E., 2005. Marine reserves enhance abundance but not competitive impacts of a harvested nonindigenous species. Ecology 86: 487-500.

Carlton, J. T., J. B. Geller, M. L. Reaka-Kudla \& E. A. Norse, 1999. An historical extinctions in the sea. Annual Review of Ecology, Evolution, and Systematics 30: 515-538.

Cherry, D. S., J. L. Scheller, N. L. Cooper \& J. R. Bidwell, 2005. Potential effects of Asian clam (Corbicula fluminea) dieoffs on native freshwater mussels (Unionidae) I: watercolumn ammonia levels and ammonia toxicity. Journal of the North American Benthological Society 24: 369-380.

Clarke, A. H., 1988. Aspects of corbiculid-unionid sympatry in the United States. Malacology Data Net 2: 57-99.

Connell, J. H., 1983. On the prevalence and relative importance of interspecific competition: evidence from field experiments. The American Naturalist 122: 661-696.

Cope, N. J. \& M. J. Winterbourn, 2004. Competitive interactions between two successful molluscan invaders of freshwaters: an experimental study. Aquatic Ecology 38: 83-91.

Crespo, D., M. Dolbeth, S. Leston, R. Sousa \& M. A. Pardal, 2015. Distribution of Corbicula fluminea in the invaded range: a geographic approach with notes on species traits variability. Biological Invasions 17: 2087-2101.
Crooks, J. A., 2001. Assessing invader roles within changing ecosystems: historical and experimental perspectives on an exotic mussel in an urbanized lagoon. Biological Invasions 3: 23-36.

Crooks, J. A., 2005. Lag times and exotic species: the ecology and management of biological invasions in slow-motion. Ecoscience 12: 316-329.

Dias, E., P. Morais, C. Antunes \& J. C. Hoffman, 2014. Linking terrestrial and benthic estuarine ecosystems: organic matter sources supporting the high secondary production of a nonindigenous bivalve. Biological Invasions 16: 2163-2179.

Douda, K., M. Lopes-Lima, M. Hinzmann, J. Machado, S. Varandas, A. Teixeira \& R. Sousa, 2013. Biotic homogenization as a threat to native affiliate species: fish introductions dilute freshwater mussels's resources. Diversity and Distributions 19: 933-942.

Downing, J. A., Y. Rochon, M. Pérusse \& H. Harvey, 1993. Spatial aggregation, body size, and reproductive success in the freshwater mussel Elliptio complanata. Journal of the North American Benthological Society 12: 148-156.

Downing, J. A., P. Van Meter \& D. A. Woolnough, 2010. Suspects and evidence: a review of the causes of extirpation and decline in freshwater mussels. Animal Biodiversity and Conservation 33: 151-185.

Englund, V. \& M. Heino, 1994. Valve movement of Anodonta anatina and Unio tumidus (Bivalvia, Unionidae) in a eutrophic lake. Annales Zoologici Fennici 31: 257-262.

Ferreira-Rodríguez, N. \& I. Pardo, 2014. Abiotic controls on population structure of the invasive Corbicula fluminea (Müller, 1774) in the River Miño estuary. Fundamental and Applied Limnology 184: 329-339.

Ferreira-Rodríguez, N. \& I. Pardo, 2016. An experimental approach to assess Corbicula fluminea (Müller, 1774) resistance to osmotic stress in estuarine habitats. Estuarine, Coastal and Shelf Science 176: 110-116.

Froufe, E., D. V. Gonçalves, A. Teixeira, R. Sousa, S. Varandas, M. Ghamizi, A. Zieritz \& M. Lopes-Lima, 2016. Who lives where? Molecular and morphometric analyses clarify which Unio species (Unionida, Mollusca) inhabit the southwestern Palearctic region. Organisms Diversity \& Evolution 16: 597-611.

Gabbott, P. \& B. L. Bayne, 1973. Biochemical effects of temperature and nutritive stress in Mytilus edulis. Journal of the Marine Biological Association of the UK 53: 287-298.

Gurnell, J., L. A. Wauters, P. W. W. Lurz \& G. Tosi, 2005. Alien species and interspecific competition: effects of introduced eastern grey squirrels on red squirrel population dynamics. Animal Ecology 73: 26-35.

Haag, W. R. \& A. L. Rypel, 2010. Growth and longevity in freshwater mussels: evolutionary and conservation implications. Biological Reviews 86: 225-247.

Hakenkamp, C. C., S. G. Ribblett, M. A. Palmer, C. M. Swan, J. W. Reid \& M. R. Goodison, 2001. The impact of an introduced bivalve (Corbicula fluminea) on the benthos of a sandy stream. Freshwater Biology 46: 491-501.

Hamza-Chaffai, A., J. Pellerin \& J. C. Amiard, 2003. Health assessment of a marine bivalve Ruditapes decussatus from the Gulf of Gabe's (Tunisia). Environment International 28: 609-617.

Hebert, P. D. N., C. C. Wilson, M. H. Murdoch \& R. Lazar, 1991. Demography and ecological impacts of the invading 
mollusc Dreissena polymorpha. Canadian Journal of Zoology 69: 405-409.

Ilarri, M., F. Freitas, S. Costa-Dias, C. Antunes, L. Guilhermino $\&$ R. Sousa, 2012. Associated macrozoobenthos with the invasive Asian clam Corbicula fluminea. Journal of Sea Research 72: 113-120.

Ilarri, M. I., A. T. Souza, C. Antunes, L. Guilhermino \& R. Sousa, 2014. Influence of the Asian clam Corbicula $f u$ minea (Bivalvia: Corbiculidae) on estuarine epibenthic assemblages. Estuarine, Coastal and Shelf Science 143: $12-19$.

Isom, B. G., 1986. Historical review of Asiatic bivalve (Corbicula) invasion and biofouling of waters and industries in the Americas. American Malacological Bulletin Special Edition 2: 1-6.

Jokela, J. \& P. Mutikainen, 1995. Effect of size-dependent muskrat (Ondatra zibethica) predation on the spatial distribution of a freshwater clam, Anodonta piscinalis Nilsson (Unionidae, Bivalvia). Canadian Journal of Zoology 73: 1085-1109.

Johnson, P. D. \& R. G. McMahon, 1998. Effects of temperature and chronic hypoxia on survivorship of zebra mussels (Dreissena polymorpha) and Asian clam (Corbicula fluminea). Canadian Journal of Fisheries and Aquatic Sciences 55: 1564-1572.

Kraemer, L. R., 1979. Corbicula (Bivalvia: Sphaeriacea) vs. indigenous mussels (Bivalvia: Unionacea) in U.S. rivers: a hard case for interspecific competition? American Zoologist 19: 1085-1096.

Krebs, R. A., E. M. Barkett \& M. T. Begley, 2015. The impact of dreissenid mussels on growth of the fragile papershell (Leptodea fragilis), the most abundant unionid species in Lake Erie. Canadian Journal of Zoology 93: 143-148.

Krumholz, L. A., R. L. Bingham \& E. R. Meyer, 1969. A survey of the commercially valuable mussels of the Wabash and White Rivers of Indiana. Proceedings of the Indiana Academy of Science 79: 205-226.

Lagadic, L., T. Caquet, J.-C. Amiard \& F. Ramade, 1997. Biomarqueurs en écotoxicologie. Aspects fondamentaux. Masson, Paris.

Leff, L. G., J. L. Burch \& J. V. McArthur, 1990. Spatial distribution, seston removal, and potential competitive interactions of the bivalves Corbicula fluminea and Elliptio complanata in a coastal plain stream. Freshwater Biology 24: 409-416.

Lopes-Lima, M., A. Teixeira, E. Froufe, A. Lopes, S. Varandas \& R. Sousa, 2014. Biology and conservation of freshwater bivalves: past, present and future perspectives. Hydrobiologia 735: 1-13.

Lopes-Lima, M., R. Sousa, J. Geist, D. C. Aldridge, R. Araujo, J. Bergengren, Y. Bespalaya, E. Bódis, L. Burlakova, D. Van Damme, K. Douda, E. Froufe, D. Georgiev, C. Gumpinger, A. Karatayev, U. Kebapci, I. Killeen, J. Lajtner, B. Larsen, R. Lauceri, A. Legakis, S. Lois, S. Lundberg, E. Moorkens, G. Motte, K.-O. Nagel, P. Ondina, A. Outeiro, M. Paunovic, V. Prié, T. von Proschwitz, N. Riccardi, M. Rudzīte, M. Rudzītis, C. Scheder, M. Seddon, H. Şereflişan, V. Simic, S. Sokolova, K. Stoeckl, J. Taskinen, A. Teixeira, F. Thielen, T. Trichkova, S. Varandas, H. Vicentini, K. Zajac, T. Zajac \& S. Zogaris, 2016. Conservation status of freshwater mussels in Europe: state of the art and future challenges. Biological Reviews. doi:10.1111/brv.12244.

Lydeard, C., H. Cowie, W. F. Ponder, A. E. Bogan, P. Bouchet, S. A. Clark, K. S. Cummings, T. J. Frest, O. Gargominy, D. G. Herbert, R. Hershler, K. E. Perez, B. Roth, M. Seddon, E. E. Strong \& F. G. Thompson, 2004. The global decline of nonmarine mollusks. BioScience 54: 321-330.

McCorkle, S., T. C. Shirley \& T. H. Dietz, 1979. Rhythms of activity and oxygen consumption in the common pond clam, Ligumia subrostrata (Say). Canadian Journal of Zoology 57: 1960-1964.

McIntosh, A. R., C. R. Townsend \& T. A. Crow, 1992. Competition for space between introduced brown trout (Salmo trutta L.) and a native galaxiid (Galaxias vulgaris Stokell) in a New Zealand stream. Journal of Fish Biology 41: 63-81.

McMahon, R. F., 1991. Mollusca: Bivalvia. In Thorp, J. H. \& A. P. Covich (eds), Ecology and Classification of North American Freshwater Invertebrates. Academic Press, San Diego: 315-390.

McMahon, R. F., 2000. Invasive characteristics of freshwater bivalve Corbicula fluminea. In Claudi, R. \& J. Leach (eds), Nonindigenous freshwater organisms: vectors, biology, and impacts. Lewis Publishers, Florida: 315-343.

McMahon, R. F., 2002. Evolutionary and physiological adaptations of aquatic invasive animals: $\mathrm{r}$ selection versus resistance. Canadian Journal of Fisheries and Aquatic Sciences 59: 1235-1244.

Morais, P., M. M. Rufino, J. Reis, E. Dias \& R. Sousa, 2014. Assessing the morphological variability of Unio delphinus. Journal of Molluscan Studies 80: 17-23.

Murdoch, W. W., C. J. Briggs \& R. M. Nisbet, 1996. Competitive displacement and biological control in parasitoids: a model. American Naturalist 148: 807-826.

Newell, R. I. E., 1985. Physiological effects of the MSX parasite Haplosporidium nelsoni (Haskin, Stauber and Mackin) on the American oyster Crassostrea virginica (Gmelin). Journal of Shellfish Restoration 5: 91-95.

Neves, R. J. \& S. N. Moyer, 1988. Evaluation of techniques for age determination of freshwater mussels (Unionidae). American Malacological Bulletin 6: 179-188.

Novais, A., A. Souza, M. Ilarri, C. Pascoal \& R. Sousa, 2015. Facilitation in the low intertidal: effects of an invasive species on the structure of an estuarine macrozoobenthic assemblage. Marine Ecology Progress Series 522: 157-167.

Novais, A., E. Dias \& R. Sousa, 2016a. Inter and intraspecific variation of carbon and nitrogen stable isotopes ratios in freshwater bivalves. Hydrobiologia 765: 149-158.

Novais, A., A. Souza, M. Ilarri, C. Pascoal \& R. Sousa, 2016 b. Effects of the invasive clam Corbicula fluminea (Müller, 1774) on an estuarine microbial community. Science of the Total Environment 566-567: 1168-1175.

Patzner, R. A. \& D. Müller, 2001. Effects of eutrophication on Unionids. In Bauer, G. \& K. Watchtler (eds), Ecology and evolution of freshwater mussels Unionoida. Springer, Berlin: 327-335.

Pérez-Quintero, J. C., 2011. Freshwater mollusc biodiversity and conservation in two stressed Mediterranean basins. Limnologica 41: 201-212. 
Pilotto, F., R. Sousa \& D. C. Aldridge, 2016. Is the body condition of the invasive zebra mussel (Dreissena polymorpha) enhanced through attachment to native freshwater mussels (Bivalvia, Unionidae)? Science of the Total Environment 553: 243-249.

Reis, J., A. Machordom \& R. Araujo, 2013. Morphological and molecular diversity of Unionidae (Mollusca, Bivalvia) from Portugal. Graellsia 69: 16-36.

Riisgård, H. U., C. Kittner \& D. F. Seerup, 2003. Regulation of opening state and filtration rate in filter-feeding bivalves (Cardium edule, Mytilus edulis, Mya arenaria) in response to low algal concentration. Journal of experimental marine biology and ecology 284: 105-127.

Santos, R. M. B., L. F. S. Fernandes, S. G. P. Varandas, M. G. Pereira, R. Sousa, A. Teixeira, M. Lopes-Lima, M. V. R. Cortes \& F. A. L. Pacheco, 2015. Impacts of climate change and land-use scenarios on Margaritifera margaritifera, an environmental indicator and endangered species. Science of the Total Environment 511: 477-488.

Schoener, T. W., 1983. Field experiments on interspecific competition. The American Naturalist 122: 240-285.

Sousa, R., L. Guilhermino \& C. Antunes, 2005. Molluscan fauna in the freshwater tidal area of the River Minho estuary, NW of Iberian Peninsula. Annales de Limnologie - International Journal of Limnology 41: 141-147.

Sousa, R., C. Antunes \& L. Guilhermino, 2007. Species composition and monthly variation of the Molluscan fauna in the freshwater subtidal area of the River Minho estuary. Estuarine, Coastal and Shelf Science 75: 90-100.

Sousa, R., S. Dias, L. Guilhermino \& C. Antunes, 2008a. Minho River tidal freshwater wetlands: threats to faunal biodiversity. Aquatic Biology 3: 237-250.

Sousa, R., C. Antunes \& L. Guilhermino, 2008b. Ecology of the invasive Asian clam Corbicula fluminea (Müller, 1774) in aquatic ecosystems: an overview. Annales Limnologie International Journal of Limnology 44: 85-94.

Sousa, R., P. Morais, C. Antunes \& L. Guilhermino, 2008c. Factors affecting Pisidium amnicum (Müller, 1774; Bivalvia: Sphaeriidae) distribution in the River Minho estuary: consequences for its conservation. Estuaries and Coasts 31: 1198-1207.

Sousa, R., A. J. A. Nogueira, C. Antunes \& L. Guilhermino, 2008d. Growth and production of Pisidium amnicum (Müller, 1774) in the freshwater tidal area of the River Minho estuary. Estuarine, Coastal and Shelf Science 79: 467-474.

Sousa, R., A. J. A. Nogueira, M. Gaspar, C. Antunes \& L. Guilhermino, 2008e. Growth and extremely high production of the non-indigenous invasive species Corbicula fluminea (Müller, 1774): possible implications for ecosystem functioning. Estuarine, Coastal and Shelf Science 80: 289-295.

Sousa, R., M. Rufino, M. Gaspar, C. Antunes \& L. Guilhermino, 2008f. Abiotic impacts on spatial and temporal distribution of Corbicula fluminea (Müller, 1774) in the River Minho estuary, Portugal. Aquatic Conservation: Marine and Freshwater Ecosystems 18: 98-110.

Sousa, R., F. Pilotto \& D. C. Aldridge, 2011a. Fouling of European freshwater bivalves (Unionidae) by the invasive zebra mussel (Dreissena polymorpha). Freshwater Biology 56: $867-876$.
Sousa, R., M. Ilarri, A. T. Souza, C. Antunes \& L. Guilhermino, 2011b. Rapid decline of the greater European peaclam at the periphery of its distribution. Annales Limnologie International Journal of Limnology 47: 211-219.

Sousa, R., A. Novais, R. Costa \& D. Strayer, 2014. Invasive bivalves in fresh waters: impacts from individuals to ecosystems and possible control strategies. Hydrobiologia 735: 233-251.

Sousa, R., S. Varandas, A. Teixeira, M. Ghamizi, E. Froufe \& M. Lopes-Lima, 2016. Pearl mussels (Margaritifera marocana) in Morocco: conservation status of the rarest bivalve in African fresh waters. Science of the Total Environment 547: 405-412.

Strayer, D. L., 1999. Effects of alien species on freshwater mollusks in North America. Journal of the North American Benthological Society 18: 74-98.

Strayer, D. L., J. A. Downing, W. R. Haag, T. L. King, J. B. Layzer, T. J. Newton \& S. J. Nichols, 2004. Changing perspectives on pearly mussels, North America's most imperiled animals. BioScience 54: 429-439.

Tankoua, O. F., C. Amiard-Triquet, F. Denis, C. Minier, C. Mouneyrac \& B. Berthet, 2012. Physiological status and intersex in the endobenthic bivalve Scrobicularia plana from thirteen estuaries in northwest France. Environmental Pollution 167: 70-77.

Tlili, S., I. Métais, N. Ayache, H. Boussetta \& C. Mouneyrac, 2011. Is the reproduction of Donax trunculus affected by their sites of origin contrasted by their level of contamination? Chemosphere 84: 1362-1370.

Trueman, E. R., 1983. Locomotion in mollusc. In Rusell-Hunter, W. D. (ed.), The Mollusca. Academic Press, New York: $155-194$.

Vaughn, C. C. \& C. M. Taylor, 1999. Impoundments of and decline of freshwater mussels: a case study of an extinction gradient. Conservation Biology 13: 912-920.

Vaughn, C. C. \& C. C. Hakenkamp, 2001. The functional role of burrowing bivalves in freshwater ecosystems. Freshwater Biology 46: 1431-1446.

Vaughn, C. C. \& D. E. Spooner, 2006. Scale-dependent associations between native freshwater mussels and invasive Corbicula. Hydrobiologia 568: 331-339.

Wiens, J. A., 1977. On competition and variable environments. American Scientist 65: 590-597.

Williams, J. D., M. L. Warren, K. S. Cummings, J. L. Harris \& R. J. Neves, 1998. Conservation status of freshwater mussels of the United States and Canada. Fisheries 18: 6-22.

Xie, Q. \& G. M. Burnell, 1995. The effect of activity on the physiological rates of two clam species, Tapes philippinarum (Adams \& Reeve) and Tapes decussatus (Linnaeus). Biology and Environment: Proceedings of the Royal Irish Academy 95: 217-223.

Zhang, C., Y. Tang, L. Luoc \& W. Xuc, 2009. Outlier identification and visualization for $\mathrm{Pb}$ concentrations in urban soils and its implications for identification of potential contaminated land. Environmental Pollution 157: 3083-3090.

Zieritz, A., M. Lopes-Lima, A. Bogan, S. Sousa, S. Walton, K. Rahim, J.-J. Wilson, P.-Y. Ng, E. Froufe \& S. McGowan, in press. Factors driving changes in freshwater mussel (Bivalvia, Unionida) diversity and distribution in Peninsular Malaysia. Science of the Total Environment. 